\title{
KONFLIK PERAN GANDA DAN KEBERFUNGSIAN KELUARGA PADA IBU YANG BEKERJA
}

\author{
Zarina Akbar* \\ Kharisma Kartika** \\ *Fakultas Pendidikan Psikologi, Universitas Negeri Jakarta \\ **Fakultas Pendidikan Psikologi, Universitas Negeri Jakarta
}

DOI: https://doi.org/10.21009/JPPP.052.02

\author{
Alamat Korespondensi: \\ zarina_akbar@unj.ac.id \\ kharismatika15@gmail.com
}

\begin{abstract}
This research aimed to determine the influence of work-family conflict to the family functioning between working mother. The research using quantitative. The sample were 100 working mother $(n=100)$ by using the method purposive sampling. The data using a questionnaire with an instrument work-family conflict scales (40 item) and family assessment device (52 item). Statistical data is done by using Rasch Model in the form of software Winstep and SPSS 23.0. Results of research indicate that there is influence of work-family conflict to the family functioning between working mother. The value of $F_{\text {hit }}>F_{\text {tabel }}(59,08>3,94)$ and $R$ square value equal to 0,376 .
\end{abstract}

Keywords:

work-family conflict, family functioning, working mother

\section{Pendahuluan}

Secara tradisional pada konteks budaya negaranegara di Asia, wanita yang sudah menikah diharapkan untuk dapat tinggal di rumah dan menjaga kesejahteraan anak-anak dan keluarga mereka. Seiring dengan perkembangan zaman, wanita dituntut untuk memberikan sumbangan lebih, tidak hanya terbatas pada pelayanan terhadap suami, perawatan anak, serta menjadi pengurus rumah tangga. Saat ini, posisi wanita yang sudah menikah telah berubah secara signifikan dan memasuki dunia pekerja menjadi wanita pekerja yang sukses dan ibu serta istri pada saat yang bersamaan. Menurut Encyclopedia of Children's Health, ibuyang bekerja adalah seorang ibu yang memiliki pekerjaan di luar rumah untuk mendapatkan penghasilan di samping membesarkan dan mengurus anak di rumah. Menurut Lerner (2001) ibu yang bekerja adalah ibu yang memiliki anak dari umur 0-18 tahun dan menjadi tenaga kerja. Adanya tekanan dari faktor ekonomi serta adanya keinginan psikologis untuk mengembangkan self identity telah mendorong wanita untuk bekerja di luar rumah mengembangkan karir serta berpartisipasi secara aktif dalam kehidupan bermasyarakat (Kusumaning \& Suparmi, 2002). Salah satu tujuan ibu yang bekerja adalah suatu bentuk aktualisasi diri guna menerapkan ilmu yang telah dimiliki dan menjalin hubungan sosial dengan orang lain dalam bidang pekerjaan yang dipilihnya (Santrock, 2007).

Pekerjaan bagi seorang wanita dapat memberikan dampak positif maupun negatif. Dampak positifnya adalah melalui pekerjaannya, wanita dapat membantu suami dalam hal finansial, mencari penghasilan yang layak untuk menghidupi diri dan keluarganya, meningkatkan rasa percaya diri dan kesempatan untuk mendapatkan kepuasan hidup (Istiani, 1989). Nyoman (2003) menyatakan 
adanya perubahan demografi tenaga kerja seperti peningkatan jumlah wanita yang bekerja dan pasangan suami-istri yang keduanya bekerja telah meningkatkan hubungan ketergantungan antara pekerjaan dan keluarga serta mendorong konflik antara tuntutan peran pekerjaan maupun peran keluarga.

Keluarga adalah sekelompok orang dengan ikatan perkawinan, darah, atau adopsi; terdiri dari satu orang kepala rumah tangga, interaksi dan komunikasi satu sama lainnya dalam peran suami istri yang saling menghormati, ibu dan ayah, anak laki-laki dan perempuan, saudara laki-laki dan perempuan, dan menciptakan serta mempertahankan kebudayaannya Burgess \& Locke (dalam Duvall \& Miller, 1985). Keluarga merupakan suatu sistem sosial yang terbuka, karena itu sistem yang berada di luar keluarga sangat berpengaruh terhadap kehidupan keluarga, baik berpengaruh terhadap struktur keluarga maupun pola interaksi yang berada di dalamnya. Sebagai suatu sistem sosial, keluarga merupakan subsistem dari sistemsistem yang lebih luas, yaitu lingkungan tetangga, komunitas, dan masyarakat yang lebih besar (Bronferenbrenner, 1979). Keluarga memainkan peranan penting dalam membangun kesejahteraan, pengasuhan dan pendidikan dasar kepada anggota-anggota keluarga (Fahrudin, 2005).

Interaksi dalam keluarga sangat berkaitan dengan keberfungsian keluarga karena dalam interaksi itulah keluarga menjaga pertumbuhan dan kesejahteraan dari masing-masing anggotanya (Walsh, 2003). Keberfungsian keluarga adalah sejauh mana sebuah keluarga dapat menjalankan tugas-tugasnya dengan tetap dapat mengupayakan kesejahteraan dan perkembangan sosial, fisik, dan psikologis masing-masing anggotanya (Epstein, Ryan, Bishop, Miller, \& Keitner, 2003; DeFrain, Asay, \& Olson, 2009). McArthur (2000) menambahkan definisi keberfungsian keluarga sebagai keluarga yang dapat menjalankan fungsinya dengan benar. Keberfungsian keluarga menjadi tempat individu dapat tumbuh menjadi dirinya sendiri, di dalamnya terdapat rasa cinta dan kebersamaan antara anggota keluarga. Antar anggota keluarga memberikan waktu dan dukungan antara satu dengan yang lain, peduli terhadap keluarga, dan membuat kesejahteraan anggota keluarga menjadi prioritas dalam kehidupan.Kesejahteraan keluarga merupakan output dari berjalannya sebuah ketahanan keluarga, yaitu kemampuan keluarga mengelola sumber daya baik yang dimiliki ataupun tidak dimiliki namun dapat diakses keluarga, serta mengelola masalah yang dihadapi keluarga untuk memenuhi tujuan keluarga (Sunari, 2010).

Perubahan sosial yang berlangsung cepat, industrialisasi, dan urbanisasi dipandang sebagai faktor yang dapat menyebabkan disorganisasi keluarga (Thomas \& Wilcox dalam Sussman \& Steinmetz, 1987). Menurut Gutek (dalam Aycan \& Eskin, 2005), faktor dalam pekerjaan akan memengaruhi kehidupan keluarga dan sebaliknya faktor dalam keluarga akan memengaruhi pekerjaan. Menurut penelitian Apperson (2002) mayoritas pria dan wanita sekarang ini, mempunyai kedudukan ganda, sebagai orang tua dan juga sebagai karyawan dengan jenis pekerjaan fulltime. Primastuti (2000) menjelaskan bahwa banyak dari mereka yang memainkan peranan ganda dalam dunia kerja untuk mendapatkan penghasilan ataupun kepuasan. Konflik antara pekerjaan dan keluarga dapat terjadi baik pada wanita maupun pria.

PenelitianApperson (2002) menemukan bahwa ada beberapa perbedaan tingkatan konflik peran ganda antara pria dan wanita, bahwa wanita mengalami konflik peran ganda pada tingkat yang lebih tinggi dibandingkan pria. Hal tersebut dikarenakan wanita memandang keluarga merupakan suatu kewajiban utama mereka dan harus mendapatkan perhatian lebih dibanding pada peranan pekerja mereka. Di sisi lain, wanita dituntut untuk dapat menyelesaikan pekerjaannya dengan baik dan tentu saja wanita yang sudah berumah tangga membutuhkan perhatian kepada hal yang lainnya, yaitu keluarga. Pada saat ketidakseimbangan ini terjadi maka akan mengakibatkan adanya konflik peran ganda. Konflik peran ganda pada wanita terjadi ketika wanita dituntut untuk memenuhi harapan perannya dalam keluarga dan dalam pekerjaan, dimana masing-masing membutuhkan waktu, energi, maupun komitmen dari wanita tersebut (Netemeyer, 1996).

Wanita pekerja yang sudah menikah dan memiliki anak akan menghadapi tantangan dalam peran ganda. Di satu sisi, wanita pekerja yang telah menikah memiliki kewajiban untuk berperan sebagai ibu, untuk mengurus pekerjaan rumah tangga, dan di sisi lain berperan sebagai karyawati 
yang memiliki kewajiban untuk memenuhi tuntutan tugas karyawan. Hal-hal tersebut mungkin menjadi kecemasan tersendiri bagi mereka terutama dari faktor lingkungan. Saat kedua peran pekerjaan tidak berjalan dengan selaras maka dikhawatirkan akan menimbulkan kecemasan serta masalah terhadap keluarga.

Greenhaus \& Beutell (dalam Bellavia \& Frone, 2005) menjelaskan bahwa konflik peran ganda adalah suatu bentuk konflik antar peran dimana peran dari ranah pekerjaan dan keluarga saling mengalami ketidakcocokan dalam beberapa hal. Higgins, Duxbury \& Lee (1994) menggambarkan bahwa gender memengaruhi peran ganda dalam hal yang berbeda. Di sisi lain, wanita menghadapi lebih banyak konflik dari domain keluarga dan pria menghadapi lebih banyak konflik dari domain pekerjaan (Jaros, 1993). Hochschild, Arlie, \& Machung (1989) memastikan bahwa wanita menghabiskan banyak waktu pada tanggung jawab keluarga dibandingkan pria dan hal tersebut menjadikan wanita menghabiskan lebih banyak waktu dalam memanage antara tanggung jawab pekerjaan serta keluarga. Pleck, Staines, and Lang (1980) menambahkan bahwa terdapat faktor-faktor spesifik misalnya, jam kerja yang panjang dan kesalahan kepengurusan jadwal menambah konflik pekerjaan-keluarga, dan wanita menikah menghadapi konflik peran ganda karena jadwal yang tidak kompatibel dan pria yang menikah menghadapi konflik peran ganda karena jam kerja yang berlebihan.

Perubahan demografi tenaga kerja seperti peningkatan jumlah wanita bekerja dan pasangan suami-isteri yang keduanya bekerja telah meningkatkan hubungan ketergantungan antara pekerjaan dan keluarga serta mendorong konflik antara tuntutan pekerjaan dan keluarga. Perubahan ini juga meningkatan perhatian publik dan menuntut pemilik perusahaan untuk mengadaptasi kebijakan-kebijakan yang berhubungan dengan pekerjaan dan keluarga (Goodstein,1994).

Konflik peran ganda berhubungan sangat kuat dengan depresi dan kecemasan yang diderita oleh wanita dibandingkan pria (Frone, 2000). Hal ini berhubungan dengan peran tradisional wanita yang hingga saat ini tidak bisa dihindari, yaitu tanggung-jawab dalam mengatur rumah tangga dan membesarkan anak. Menurut Abbott, Cieri, \& Iverson (1998) meskipun konfik peran ganda disadari merupakan masalah bagi pria maupun wanita, masalah tersebut tetap saja memberikan tanggung jawab tambahan bagi wanita yang memiliki keluarga dan bekerja. Seorang wanita profesional yang telah menikah dan memiliki status karir yang sama dengan suaminya, tetap menghadapi pola tradisional yang tidak seimbang dalam tugas menjaga anak dan pekerjaan rumah tangga sehari-hari (Vinokur, Pierce, \& Buck, 1999). Sehubungan dengan peran tradisional tersebut, sumber utama konflik peran ganda yang dihadapi oleh wanita bekerja pada umumnya adalah usahanya dalam membagi waktu atau menyeimbangkan tuntutan pekerjaan dan tuntutan keluarganya.

Ammons dan Beutell (dalam Hartini, 2009) menyatakan bahwa individu dengan pendidikan rendah cenderung mengalami konflik dari keluarga kemudian memengaruhi pekerjaan sedangkan individu yang memiliki pendidikan tinggi cenderung mengalami konflik dari pekerjaan yang memengaruhi keluarga karena hal ini terkait dengan strategi dalam mengatur tanggung jawab antara pekerjaan dan keluarga. Masalah yang dihadapi oleh wanita yang bekerja adalah ketika kedua peran yang dimiliki sebagai istri atau ibu rumah tangga serta peran sebagai wanita pekerja mengalami tekanan. Peran ganda yang dimiliki oleh ibu bekerja di satu sisi menjadi ibu yang sabar dan bijaksana untuk anak-anak serta menjadi istri yang baik bagi suami serta menjadi ibu rumah tangga yang bertanggung jawab atas keperluan dan urusan rumah tangga. Di tempat kerja, ibu bekerja juga memiliki komitmen dan tanggung jawab atas pekerjaan yang dipercayakan pada mereka hingga mereka harus menunjukkan prestasi kerja yang baik (Rini, 2002).

Greenhaus \& Beutell (1985) mendefinisikan konflik peran ganda antara pekerjaan dan keluarga sebagai sebuah bentuk dari konflik antar peran dimana tekanan dari peran dalam pekerjaan dan keluarga saling bertentangan, yaitu menjalankan peran dalam pekerjaan menjadi lebih sulit karena juga menjalankan peran dalam keluarga, begitu juga sebaliknya, menjalankan peran dalam keluarga menjadi lebih sulit karena juga menjalankan peran dalam pekerjaan.

Herman \& Gyllstrom (1985) menemukan bahwa orang yang telah menikah mengalami konflik peran ganda yang lebih tinggi dibandingkan 
dengan orang yang belum menikah, apalagi jika memiliki anak. Hal tersebut didukung oleh pernyataan Fuchs (dalam Nichols, 1994), bahwa wanita yang mempunyai anak cenderung berada di bawah tekanan yang besar, terlebih lagi jika harus bekerja. Menurut Bohen dan Viveros-Long (dalam Greenhaus \& Beautell, 1985) tanggung jawab utama dalam rumah tangga yaitu mengasuh anak mungkin menjadi kontributif yang signifikan pada konflik peran ganda.

Dalam studi Greenhaus dan Beautell (dalam Willis, O'Conner, \& Smith, 2008), konflik peran ganda didefinisikan sebagai konsekuensi dari tuntutan yang tidak konsisten antara peran di tempat kerja dan keluarga. Dengan kata lain, konflik peran ganda terjadi ketika harapan yang berkaitan dengan peran tertentu tidak memenuhi persyaratan pada peran lainnya dan menghambat kinerja efisien dari peran itu (Greenhaus, Tammy, \& Spectors, 2006).

The National Institutefor Occupational Safety and Health mengidentifikasikan konflik peran ganda sebagai satu dari sepuluh sumber tekanan utama di tempat kerja (dalam Robbins, 2004). Penelitian dari Berk (dalam Gutek, 1991) menemukan bahwa wanita cenderung menghabiskan lebih banyak waktu dalam hal urusan keluarga sehingga wanita dilaporkan lebih banyak mengalami konflik peran ganda khususnya family interference with work.

Berdasarkan penjelasan-penjelasan di atas, peneliti tertarik untuk meneliti pengaruh konflik peran ganda terhadap keberfungsian keluarga pada ibu yang bekerja.

McArthur (2000) menjelaskan definisi keberfungsian keluarga sebagai keluarga yang dapat menjalankan fungsinya dengan benar. Perpaduan dan interaksi nilai keluarga, keterampilan dan pola interaksi yang positif menjadikan keluarga memiliki keberfungsian dalam menghadapi persoalan, mampu mengurus sumber, menyusun tujuan dan melihat tantangan sebagai peluang untuk mempertahankan dan meningkatkan kualitas kehidupan dan kesejahteraan anggotaanggotanya (Fahrudin, 2012).

Menurut Epstein, Levin, dan Bishop (dalam Walsh, 2003) keberfungsian keluarga adalah sejauh mana keluarga dapat menjalankan tugastugasnya dengan tetap dapat mengupayakan kesejahteraan dan perkembangan sosial, fisik, dan psikologis masing-masing anggotanya. Keberfungsian keluarga adalah ketika keluarga dapat mengupayakan kesejahteraan dan perkembangan sosial, fisik, dan psikologis anggota keluarganya.

Secara umum keberfungsian keluarga merujuk pada kualitas kehidupan keluarga, baik pada level sistem maupun subsistem, dan berkenaan dengan kesejahteraan, kompetensi, kekuatan, dan kelemahan keluarga (Sheck dalam Lestari, 2012). Keberfungsian keluarga dapat dinilai dari tingkat kelentingan (resiliency) atau kekukuhan (strength) keluarga dalam menghadapi berbagai tantangan (Lestari, 2012).

Menurut Encyclopedia of Children'sHealth, ibu bekerja adalah seorang ibuyang bekerja di luar rumah untuk mendapatkan penghasilan disamping membesarkan dan mengurus anak di rumah. Lerner (2001), ibu bekerja adalah ibu yang memiliki anak dari umur 0-18 tahun dan menjadi tenaga kerja.

Menurut Baron \& Byrne (2004) peran adalah suatu set perilaku yang diharapkan dilakukan oleh individu yang memiliki posisi spesifik dalam suatu kelompok. Myers (1996) mendefinisikan peran sebagai suatu set norma yang menjelaskan bagaimana individu yang menyandang posisi tertentu harus bersikap. Peran ganda dapat didefinisikan dimana seseorang memiliki jabatan atau posisi atau keadaan yang lebih dari satu sehingga membuat orang tersebut memiliki tanggung jawab yang lebih banyak (Indriyani, 2009). Dengan banyaknya peran yang dimiliki seseorang, maka timbullah konflik peran ganda. Secara umum konflik dapat diartikan sebagai kondisi dimana terjadi ketidakcocokan antara nilai dan tujuan yang ingin dicapai, baik nilai atau tujuan yang ada di dalam diri sendiri maupun dalam hubungan dengan orang lain (Wijono, 2010). Irwanto (dalam Rahmadita, 2013) menjelaskan konflik dapat terjadi pada saat muncul dua kebutuhan atau lebih secara bersamaan.

Menurut Gibson dkk. (1990) konflik peran terjadi apabila seseorang dihadapkan pada suatu situasi dimana terdapat dua atau lebih persyaratan untuk melaksanakan peran yang satu dan dapat menghalangi pelaksanaan peran yang lain. Greenhaus dan Beutell (dalam Bellavia dan Frone, 2005) menjelaskan bahwa konflik peran ganda adalah suatu bentuk konflik antar peran di mana peran dalam pekerjaan dan keluarga saling 
mengalami ketidakcocokan dalam beberapa hal. Seseorang akan menghabiskan waktu yang lebih untuk digunakan dalam memenuhi peran yang penting bagi mereka, oleh karena itu bisa kekurangan waktu untuk peran yang lainnya. Greenhaus dan Beutell menyatakan bahwa seseorang yang mengalami konflik peran ganda akan merasakan ketegangan dalam bekerja. Konflik peran ini bersifat psikologis, gejala yang terlihat pada individu yang mengalami konflik peran ini antara lain adalah rasa bersalah, kegelisahan, keletihan dan frustasi. Frone dan Bellavia (2005) mendefenisikan konflik pekerjaan-keluarga sebagai konflik peran yang terjadi pada karyawan, di mana di satu sisi ia harus melakukan pekerjaan di tempat kerja dan di sisi lain ia harus memperhatikan keluarga secara utuh, sehingga sulit membedakan antara pekerjaan mengganggu keluarga dan keluarga mengganggu pekerjaan.

\section{Metode Penelitian}

Berdasarkan tipe pendekatan, penelitian ini menggunakan metode pendekatan kuantitatif. Berdasarkan karakteristik masalah yang diteliti penelitian ini menggunakan tipe penelitian kausal komparatif (causal-comparative research) karena penelitian ini bertujuan untuk mengidentifikasi fakta atau peristiwasebagai variabelyang dipengaruhi (dependent variable) dan melakukan penyelidikan terhadap variabel-variabel yang memengaruhinya (independent variable) (Sangadji \& Sopiah, 2010). Populasi dalam penelitian ini adalah ibu yang bekerja di Cilegon.

Subjek penelitian ini memiliki karakteristik sebagai berikut: ibu yang bekerja, berusia di antara 18-40 tahun, memiliki suami yang juga bekerja, dan memiliki anak minimal satu. Teknik sampling yang dilakukan dalam penelitian ini adalah teknik non probabilitas sampling. Teknik non probabilitas sampling yang digunakan adalah jenis purposive sampling. Jumlah sampel dalam penelitian ini adalah 100 orang.

Pada penelitian ini, pengumpulan data dilakukan dengan kuesioner konflik peran ganda dan keberfungsian keluarga. Kuesioner untuk variabel konflik peran ganda menggunakan alat ukut workfamily conflict scales yang dikembangkan oleh Hotmaida Elfrida Silalahi dari Universitas HKBP Nommensen Medan pada tahun 2015. Instrumen tersebut disusun berdasarkan dimensi-dimensi konflik peran ganda yang diungkap oleh Greenhaus dan Beutell (1985), yaitu: time-based conflict, strain-based conflict, dan behavior-based conflict. Skor ini merepresentasikan sejauh mana konflik peran ganda yang dialami oleh ibu yang bekerja dan terdiri dari 48 aitem. Kuesioner untuk variabel keberfungsian keluarga menggunakan Family Assessment Device (FAD) yang disusun oleh Prof. Adi berdasarkan Epstein, Levin, dan Bishop (1976). Instrumen ini mengukur bagaimana keluarga dapat memenuhi fungsinya yang dilihat melalui skor total yang dihasilkan dari setiap dimensi, yaitu dimensi penyelesaian masalah, komunikasi, peran, tanggapan afektif, keterlibatan afektif, dan pengendalian perilaku, serta dimensi umum yang mengukur keseluruhan keberfungsian keluarga. Skor ini merepresentasikan sejauh mana keluarga dapat berfungsi dengan efektif dan terdiri dari 61 aitem.

\section{Hasil dan Diskusi}

Setelah dilakukan uji coba validitas dan reliabilitas pada alat ukur konflik peran ganda dan keberfungsian keluarga, peneliti tidak memasukkan beberapa item yang memiliki koefisien korelasi rendah. Kemudian aitem-aitem lainnya dibentuk menjadi satu set instrumen penelitian yang terdiri dari skala konflik peran ganda dan skala keberfungsian keluarga.

Pelaksanaan penelitian dilakukan di beberapa wilayah di Cilegon, Banten seperti Krakatau Junction, dan Ramayana Cilegon. Teknik pengambilan sampel yang digunakan adalah metode purposive sampling. Peneliti melakukan penyebaran instrumen sebanyak 102 instrumen. Penyebaran instrumen dilakukan pada bulan Juni sampai Juli 2017. Dari 102 instrumen, hanya 100 instrumen yang dapat diolah. Dengan demikian jumlah subjek pada penelitian ini adalah sebanyak 100 orang. Proses penyebaran instrumen ini selain peneliti lakukan sendiri dengan mendatangi beberapa tempat di atas, namun ada juga yang disebar dengan bantuan teman di tempat kerjanya. Peneliti juga menggunakan jejaring sosial berupa Facebook dan Google Docs untukmenyebar instrumen penelitian pada teman-teman yang peneliti anggap memenuhi kriteria sebagai subjek dalam penelitian ini.

Data mengenai konflik peran ganda yang dialami oleh ibu yang bekerja terdiri dari 40 item. 
Dari hasil penelitian dan pengolahan data diperoleh skor minimum adalah -3,71 dan skor maksimum adalah 0,45 . Skor rata-rata adalah 1,15 dengan standar deviasinya adalah 0,91 .
Skor konflik peran ganda yang diperoleh dari penelitian ini akan dikategorikan menjadi dua yaitu kategori tinggi dan rendah.

Tabel 1. Kategorisasi Skor Konflik Peran Ganda

\begin{tabular}{ccc}
\hline Kategorisasi & Jumlah Subjek & Persentase \\
\hline Tinggi $(>-1,15)$ & 53 & 53 \\
\hline Rendah $(\leq-1,15)$ & 47 & 47 \\
\hline
\end{tabular}

Berdasarkan proses perhitungan pengkategorisasian skor konflik peran ganda yang dihitung maka dapat disimpulkan bahwa subjek penelitian yang memiliki skor konflik peran ganda lebih besar dari -1,15 dikategorikan memiliki konflik peran ganda tinggi sedangkan subjek penelitian yang memiliki skor konflik peran ganda kurang dari atau sama dengan -1,15 dikategorikan memiliki konflik peran ganda rendah.

Berdasarkan tabel di atas, diketahui bahwa terdapat 53 subjek dengan persentase 53\% yang termasuk dalam kategori konflik peran ganda tinggi dan terdapat 47 subjek dengan persentase
47\% yang termasuk dalam kategori konflik peran ganda rendah. Hal ini membuktikan bahwa lebih banyak subjek yang mengalami konflik peran ganda tinggi.

Data mengenai keberfungsian keluarga yang dialami oleh ibu yang bekerja terdiri dari 52 aitem. Dari hasil penelitian dan pengolahan data diperoleh skor minimum adalah -2,21 dan skor maksimum adalah 0,85 . Skor rata-rata adalah 0,37 dengan standar deviasinya adalah 0,53.

Skor keberfungsian keluarga yang diperoleh dari penelitian ini akan dikategorikan menjadi dua yaitu kategori tinggi dan rendah.

Tabel 2. Kategorisasi Skor Keberfungsian Keluarga

\begin{tabular}{ccc}
\hline Kategorisasi & Jumlah Subjek & Persentase \\
\hline Tinggi $(>-0,37)$ & 52 & 52 \\
\hline Rendah $(\leq-0,37)$ & 48 & 48 \\
\hline
\end{tabular}

Berdasarkan proses perhitungan pengkategorisasian skor keberfungsian keluarga yang dihitung maka dapat disimpulkan bahwa subjek penelitian yang memiliki skor keberfungsian keluarga lebih besar dari -0,37 dikategorikan memiliki keberfungsian keluarga tinggi sedangkan subjek penelitian yang memiliki skor konflik peran ganda kurang dari atau sama dengan -0,37 dikategorikan memiliki keberfungsian keluarga rendah.

Berdasarkan tabel di atas, diketahui bahwa terdapat 52 subjek dengan persentase $52 \%$ yang termasuk dalam kategori keberfungsian keluarga tinggi dan terdapat 48 subjek dengan persentase $48 \%$ yang termasuk dalam kategori keberfungsian keluarga rendah. Hal ini membuktikan bahwa lebih banyak subjek yang mengalami keberfungsian keluarga tinggi. Berdasarkan hasil pengujian dengan analisis regresi sederhana, diperoleh hasil bahwa terdapat pengaruh yang signifikan antara konflik peran ganda terhadap keberfungsian keluarga pada ibu yang bekerja. Hal ini dapat dilihat dari nilai $\mathrm{F}=59,08 ; \mathrm{p}=0,000<0,05$. Hasil pengujian hipotesis dengan menggunakan analisis regresi linear, diperoleh nilai konstanta variabel keberfungsian keluarga sebesar 0,032. Hasil koefisien regresi 0,353. Persamaan regresi berdasarkan data yang ada, yaitu: $\mathrm{Y}=0,032+$ $0,353 \mathrm{X}$. interpretasi dari persamaan tersebut adalah jika tidak ada nilai konflik peran ganda maka nilai keberfungsian keluarga adalah sebesar 0,032. Konstanta regresi $\mathrm{X}$ sebesar 0,353 menyatakan bahwa setiap penambahan 1 nilai konflik peran ganda, maka nilai keberfungsian keluarga bertambah sebesar 0,353. Hal ini berarti bahwa dalam hubungan antara konflik peran ganda dan keberfungsian keluarga pada ibu yang bekerja terjadi hubungan dengan arah yang positif.

Berdasarkan hasil perolehan data, dapat disimpulkan bahwa konflik peran ganda memiliki pengaruh yang signifikan terhadap keberfungsian 
Zarina Akbar

Kharisma Kartika

keluarga pada ibu yang bekerja. Besar sumbangan konflik peran ganda terhadap keberfungsian keluarga diketahui dengan melihat nilai $R$ Square yang diperoleh dari penelitian ini,yaitu sebesar $0,376 \%$ atau sebesar 37,6 \%. Hal tersebut menunjukkan bahwa ada faktor lain sebesar $62,4 \%$ yang memengaruhi keberfungsian keluarga pada ibu yang bekerja.

\section{Kesimpulan}

Berdasarkan penelitian yang telah dilakukan, diketahui bahwa ada pengaruh yang signifikan antara konflik peran ganda terhadap keberfungsian keluarga pada ibu yang bekerja.

\section{Daftar Pustaka}

Anafarta, N. (2010). The Relationship Between Work-Family Conflict and Job Satisfaction: A Structural Equation Modeling (SEM Approach). Turkey.

Azwar, S. (2010). Metode Penelitian. Pustaka Pelajar, Yogyakarta.

Epstein, N. B., Baldwin, L. M. \& Duane, B. S. (1983). The Mc Master Family Assessment Device. Journal of Marital and Family Therapy, 9: 171-180.

Epstein, N. B., Bishop, D. S. \& Levin, S. (1978). The Mc Master Model of Family Functioning. Journal of Marriage and Family Counseling, 4: 19-31.

Fahrudin, A. (2012). Keberfungsian Keluarga: Konsep Dan Indikator Pengukuran Dalam Penelitian. (Functioning Family: Concept And Measurement Indicator In Research). Jurnal Informasi, 17,75-81.
Konflik Peran Ganda dan Keberfungsian Keluarga pada Ibu yang Bekerja

Fahrudin, A. (2012). Keberfungsian Keluarga: Konsep dan Indikator Pengukuran dalam Penelitian. Jurnal Informasi. 17: 75-81

Herawaty, Y., Wulan, R. (2013). Hubungan antara Keberfungsian Keluarga dan Daya Juang dengan Belajar berdasar Regulasi Diri pada Remaja.

Lestari, Sri. (2012). Psikologi Keluarga: Penanaman Nilai dan Penanganan Konflik dalam Keluarga, Edisi Pertama. Kencana Prenada Media Group, Jakarta.

McArthur, J. D. (2005). Marriage and Family. Utah: School of FamilyLife at Brigham Young University

Meidah, E. (2013). Pengaruh Konflik Peran Ganda, Kecerdasan Emosional, dan Komitmen Organisasi terhadap Kinerja Perawat Wanita. Jakarta.

Puspitawati, H. (2012). Fungsi Keluarga, Pembagian Peran dan Kemitraan Gender dalam Keluarga. IPB Press, Bogor.

Rangkuti, A. A. (2012). Konsep dan Teknik Analisis Data Penelitian Kuantitatif Bidang Psikologi dan Pendidikan. FIP Press, Jakarta.

Sangadji, E. M., \& Sopiah. (2010). Metodologi Penelitian. C.V. Andi Offset, Yogyakarta.

Silalahi, H. E. (2015). Pengaruh Konflik Peran Ganda terhadap Produktivitas Karyawati yang Berkeluarga pada PT. Sarimakmur Tunggal Mandiri. Medan.

Sugiono. (2006). Metode Penelitian Pendidikan. Alfabeta, Bandung. 